Introduction

The marginalisation of beauty

The revival of beauty

Methodology

Children's perceptions of beauty

'Glowing as if they were pieces of gold'

'Beauty and love and happiness, they're all kind of in a big umbrella-thing.'

'It's cool because it's in the dirt. That makes it beautiful.'

Conclusions

\begin{abstract}
For the past 100 years beauty has been marginalised in western art and regarded as a problematic notion in a range of cultural contexts. Art educators associate experiences of beauty with passive appreciation rather than active engagement, while researchers of children's understanding of art characterise references to beauty as evidence of low levels of aesthetic development. This article draws on evidence from a recent study to challenge these assumptions.

The study explored how children describe and analyse their perceptions of beauty and how they reflect upon and articulate their experiences of beauty. 51 children in two English primary schools were asked to find and photograph images they thought were beautiful, which they shared and discussed during a series of group interviews. The discussions offer evidence of the diversity of these children's perceptions of beauty, of their awareness of how visual and formal qualities contribute towards the beauty of images and of how experiences of beauty can be meaningful and relevant to them.

The article suggests that children's responses to beauty are not merely passive but often expressive, and that some of their responses to beautiful illustrate art educators' principles of participation, individuality and self-expression. It argues that art educators should re-appraise the value of beauty in art education and reflect on its potential for raising children's levels of engagement with the visual world.
\end{abstract}

\title{
Introduction
}

In 2013 the Department for Education published a draft version of a revised national curriculum for schools in England. The document provided a rationale for the place of each subject in the curriculum, and part of justification for art and design was that it 'should instil in pupils an appreciation of beauty.' (DfE 2013: 146). When the final version of the curriculum was published, however, the reference to beauty had been removed, a revision almost certainly linked to the lukewarm reception art educators afforded it. Writing 'a cautionary tale' in this journal, Steers (2014) offered insights into the conception and development of the proposed curriculum for art, before outlining the National Society for Education in Art and Design (NSEAD)'s objections:

As it stands, the proposed national curriculum for art, craft and design is reductive. It strongly references a historical fine art led model focusing on appreciation, aesthetics and beauty in preference to a more balanced programme of study that includes contemporary, global and future gazing curriculum... We want more than appreciation. We want participation and engagement. We want inspiration, risk, imagination and challenge. (Steers 2014: 11)

Steers polarises the aims of art education, characterising notions of beauty, aesthetics and appreciation as out-dated concepts compared with principles of 'participation, engagement, inspiration, and challenge'. The NSEAD's objections almost certainly led to the deletion of the reference to beauty, confirming its irrelevance to art education. This is the context in which I conceived, planned and carried out the research reported in this article.

My research aimed to understand children's perceptions of beauty. It explored how children describe and analyse beautiful images and how they reflect upon and articulate their experiences of beauty. I wanted to find out if children value beauty, to discover what meanings it may hold for them, to understand what kinds of subject matter they find beautiful and to assess whether social, 
cultural or environmental factors influenced their preferences. The study took the form of 18 group interviews with 51 children in two schools in urban and rural locations. Before the interviews children completed two tasks independently in which they found and photographed images they thought were beautiful. This article reflects on a selection of illustrated extracts from the interview transcripts in order to provide evidence of children's levels of engagement with beauty, and begins by reflecting on the problematic place of beauty in art and education.

\section{The marginalisation of beauty}

The marginalisation of beauty in western art during the $20^{\text {th }}$ Century is well documented (e.g. Hughes 1991; Hickey 1993; Steiner 2001; Nehemas 2007). Beech suggests that what was once a 'special relationship' between beauty and art has become 'estranged and tense' (2009: 12), while Danto describes how beauty became a 'stigma' in modern art (2003: 7) and Best argues that the philosopher's 'traditional quest' to find beauty in artworks 'is now thoroughly misconceived' (1996: 81). Beyond the art world, notions of beauty have become increasingly politicised. Wolf (1991) argues that men have deliberately constructed contemporary notions of feminine beauty as subservient in nature while Freedman (2003) views with suspicion the male influence on women's aspirations for their appearance. Other commentators note how beauty is 'politically incorrect' for advocates of social equality: Jenkins recalls architect Richard Rogers' account of how the New Labour government rejected his vision of urban regeneration in the 1990s, warning him 'to avoid using words like beauty if I wanted to be taken seriously by those who counted' (2009: 3).

In this context, it is perhaps understandable that art educators perceive beauty as a problematic theme, removed from the aims of art education. Studies of children's understanding of art only rarely acknowledge that they might perceive beauty in images (Parsons 1987; Freeman 1996); moreover, their authors tend to interpret children's references to beauty as evidence of low levels of aesthetic development. Parsons suggests children believe paintings can only be beautiful if they represent beautiful subjects, illustrating his argument with a quote from Blair, aged 12: 'If you showed a woman sitting in a boat, and a lake behind her, and stuff, or a couple of deer in the mountains then that would be beautiful' (1987: 40). Parsons characterised such responses as a 'transparency view of painting' and concluded that children assume 'a painting will be beautiful if it is about a beautiful subject. Beauty is transferred, as it were, from the subject to the painting... A painting could not be beautiful if it pictured my old and rusting automobile' (1987: 40). As such, he argued, the nature of children's engagement with beauty is essentially superficial.

The absence of beauty in art education has been particularly marked since the 1980s, since when prominent UK art educators have consistently promoted engagement with issues-based contemporary art practice (e.g. Swift and Steers 1999; Atkinson and Dash 2005; Addison and Burgess 2007). Educators were acutely concerned that students should perceive art lessons to be relevant to their needs. Rod Taylor, for example, wrote enthusiastically about a pupil who ceased work on a project inspired by Degas when he encountered Gerd Winner's monochrome photographs of brick walls. Such work, Taylor argued, 'genuinely relates to pupils' own practical needs' (1989: 28). Similarly, in her analysis of visual resources available for secondary school pupils, Bancroft bemoaned the absence of images depicting 'contemporary representations of killing, war, death and disaster' (1995: 24) while applauding Taylor and Andrews' (1993) use of an image of 'the charred head of an Iraqi soldier' as it provided opportunities to 'tackle disturbing issues in the classroom' (1995: 24). The idea that children could draw inspiration from their experiences of beauty was far from the minds of art educators. 

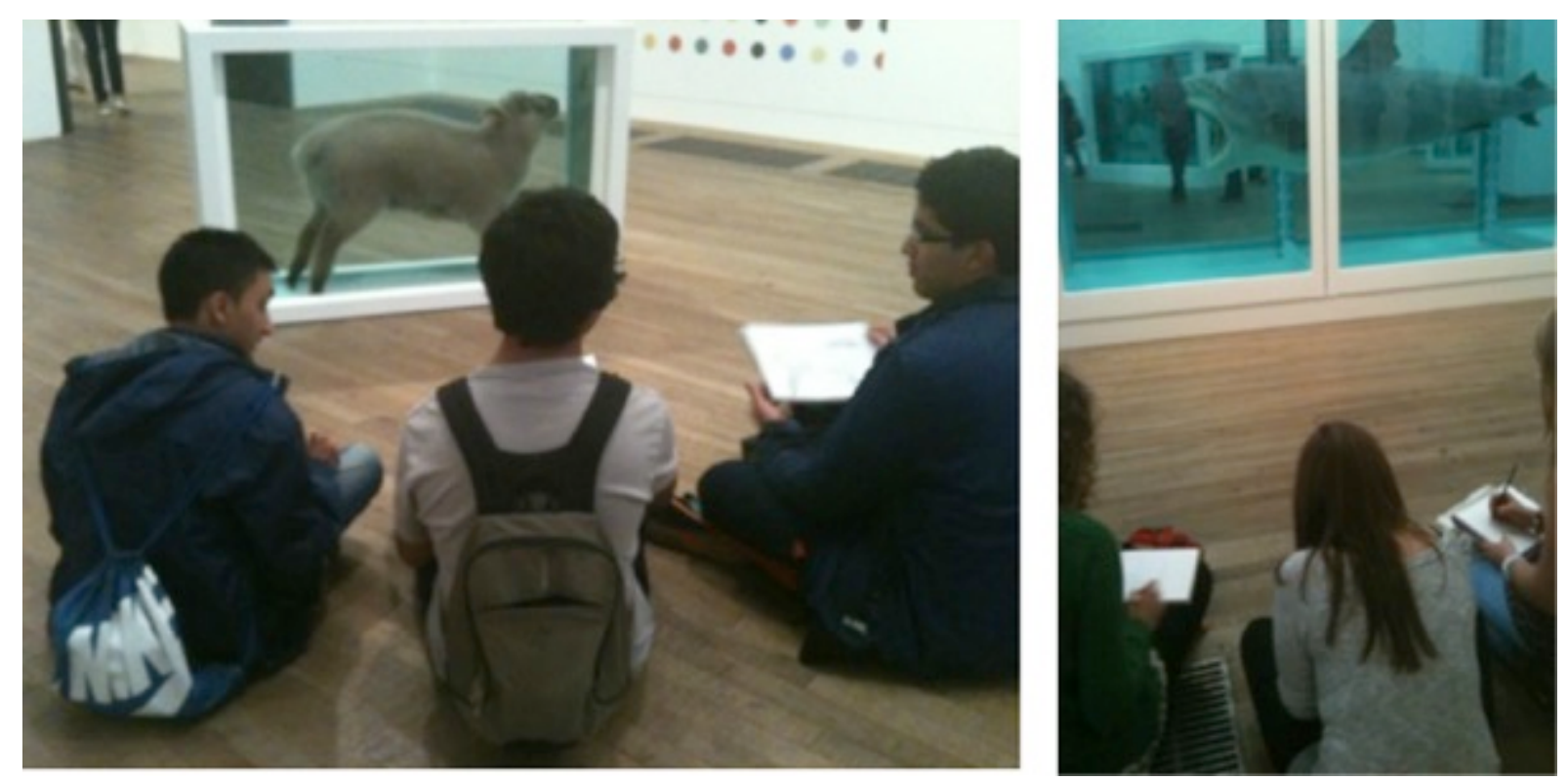

Fig 1: Secondary school pupils making drawings of works by Damien; Tate Modern, 2012 (photographs: the author)

In fairness, art educators could not have anticipated the extent to which issues-based contemporary art would shortly assume cultural prominence - and widespread acceptance - in the UK. A recent report on shifting curatorial priorities at Tate Britain indicates that modern and contemporary art dominates its displays while much of its historical collection lies in storage (Alberge 2012). In the 1980s, a disused power station languished on the banks of the Thames; in 2000, reincarnated as Tate Modern, it attracted 5.25 million visitors (Tate 2001), sustaining these numbers over a decade later (Tate 2012). In the mid-1980s, Damien Hirst was at art school; in 2008, a collection of his works sold for over $£ 70$ million (Adams 2008), while his 2012 retrospective at Tate Modern (Fig. 1) attracted 463,000 visitors, making it the most popular one-person show in the gallery's history (Tate 2012). In the current cultural climate, young people need little persuasion of the appeal of contemporary art and art educators can claim some credit for the shift in perceptions that has taken place. Yet much of the current research in art education continues to focus on approaches that foreground contemporary art practice and minimise aesthetic pleasure (Fig. 2).
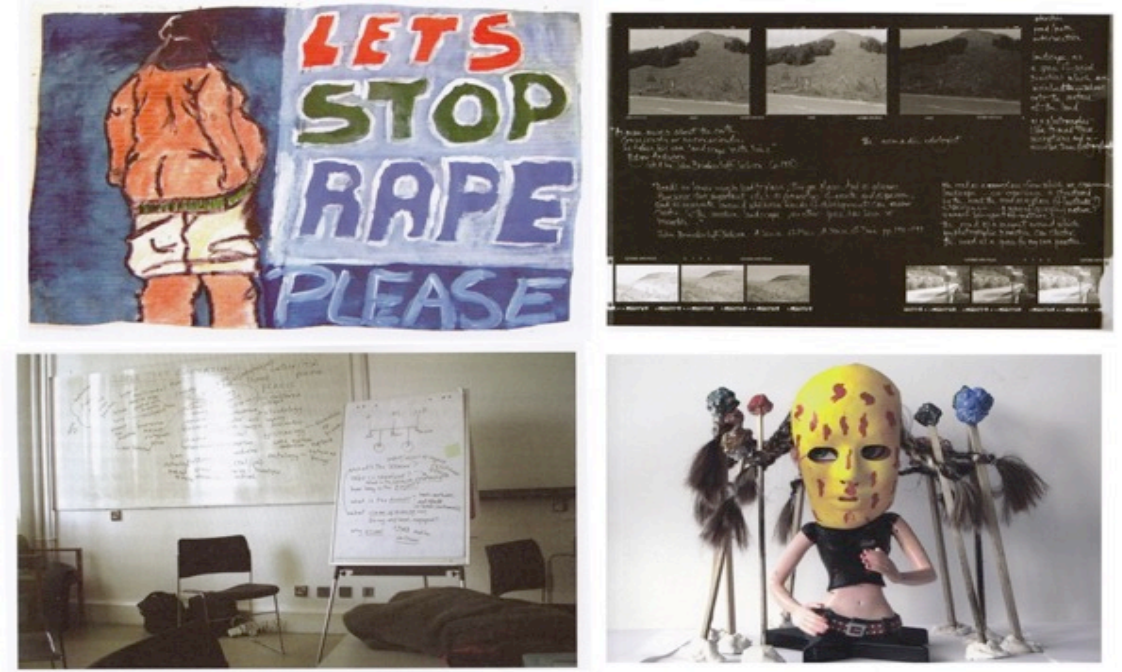

Fig. 2 Examples of images of student artwork from the International Journal of Art and Design Education, Vol. 31 . No. 3 (2012) 


\section{The revival of beauty}

Since the late $20^{\text {th }}$ Century several authors have re-appraised the place of beauty in art and contemporary culture. Some reflect on its meanings in western art and contemporary culture (Gilbert-Rolfe 1999; Danto 2003; Hickey 2009) while others examine its historical and philosophical foundations (Eco 2004; Prettejohn 2005; Nehamas 2007). Several authors explore the meanings of beauty in the context of personal, historical and cultural contexts (de Botton 2002; Sartwell 2004; Armstrong 2004; Scruton 2009; Rautio 2010) while others seek to 'reclaim' beauty in ways that distance it from the oppression of women (Steiner 2001; Scarry 2001).

There is also emerging interest in beauty in the context of education (Winston 2006, 2008; Cannatella 2010). Winston argues that beauty was previously perceived 'as one of the highest aims of education' (2008: 71), and offers a rationale for reviving its place in schools: 'The concept of beauty can inform what teachers do in progressive ways, whilst avoiding the kind of revisionist zeal that warps rather than liberates their imaginations.' (2010: 8) He suggests there are epiphanic moments, times when children make accidental discoveries they instinctively know will be important to them even if they do not understand them at the time. Rather than simply wait for inspiration to strike their pupils, teachers should seek to understand the pedagogical principles that underpin such experiences and apply them at each stage of the learning process. To begin with, Winston argues, teachers must be attuned to children's existing aesthetic interests and try to anticipate ways they might perceive images, music or books as beautiful. Rather than guide lessons towards predetermined goals that reflect their own assumptions about artworks, teachers should be prepared for unpredictable responses.

Though Winston writes from outside of the context of art education, several of his principles will be familiar to art educators. Specifically, the idea that students should produce diverse outcomes is one Elliot Eisner (e.g. 1972; 2002) and other theorists have identified as a key feature of teaching and learning in art. In another respect, Winston's ideas challenge common practice in art education. In my experience, teachers are far more likely to take responsibility for the selection of artworks to use in the classroom than they are to allow children to select images that reflect their preferences: a stimulus is therefore more likely to be subject-centred than child-centred. Winston invites teachers to reflect on how experiences of beauty in their own personal and professional lives inform their understanding of themselves and their pupils, and to consider how encouraging children's awareness of beauty can offer balance in an educational climate that values conformity above individuality, and concludes with an appeal for the 'awakening' of beauty in education.

While Winston presents a persuasive argument for the place of beauty in education, however, his work does not explore children's perspectives on the theme. How do children represent their perceptions of beauty? How do they reflect upon and articulate their perception of beauty? These questions prompted my own research. In the remainder of this article I provide a brief overview of the methodology of the study, before presenting a selection of data gathered from the study.

\section{Methodology}

The empirical research consisted of 18 semi-structured group interviews with 51 children in two schools, one in London, the other in a rural village 40 miles from the capital. The methodology is explored in detail elsewhere (Watts, Mason and Dura-Vila, forthcoming), but it is useful here to identify several innovative aspects of the design.

Firstly, whereas previous researchers (e.g. Machotka 1966; Parsons 1987; Housen 1983) provided artworks for their interviewees to respond to, I consciously avoided positioning myself as a privileged 'art expert', and made sure children provided all images shared during the interviews. Before their first interview I asked them to find images to 'represent their idea of beauty'; before the second interview I asked them to take photographs that they thought were beautiful. Secondly, I 
conducted group rather than individual interviews, recognising (a) that group interviews could help me to understand how children conceptualise and negotiate ideas (Mason 2002) and (b) that groups generate ideas more quickly, share them more confidently and are more likely to enjoy the process (Greig, Taylor and MacKay 2007). Thirdly, influenced by the principles and practice of Philosophy for Children (Lipman 1982; Fisher 1998; Worley 2010; Gaut and Gaut 2012; Lewis 2012) I designed and managed the interviews in ways that actively encouraged children to articulate their thoughts, ideas and beliefs. In particular, I drew on Fisher's (1998) concept of the teacher as a facilitator of discussion, one who focuses children on their ideas, asks for clarification and highlights connections and contrasts.

I also brought to the interviews an awareness of philosophical theories of aesthetic response. In particular I drew on Kantian and Humean theories of aesthetic experience, and asked children questions that enabled me to explore their nascent ideas about subjectivity, disinterest and universality. During the interviews I remained alert to opportunities for exploring children's perceptions of these themes and, while my questions often challenged children to think, reflect and articulate their responses, I phrased them in accessible language (e.g. If you had never visited this place would it still be beautiful to you? Should some things be beautiful to everyone?). Finally, I brought to the interviews my experience as a primary school teacher. I was relaxed in my interactions with children, tolerant of their limited concentration spans and supportive of their efforts to articulate ideas. Before the interviews I visited children's classrooms, supporting their learning informally, in order to become a familiar presence to them. I also observed their teachers' strategies for engaging and sustaining children's attention, aware that I would need to adopt similar tactics during the interviews.

Three principles guided my approach to interpreting and presenting the data: to provide faithful descriptions of children's perspectives; to identify themes that summarised their perceptions without simplifying or misrepresenting them; and to represent the diversity of children's ideas rather than foreground the most frequent responses. This last principle draws on Larsson's (2009) assertion that 'the uncommon case is as important as the most common kind of case... the variation in the study should be expected to exist also in relevant situations that one wants to generalize to' (2009: 31). These uncommon cases may not be representative of all children, but have what Strauss and Corbin describe as 'explanatory power' (1990: 61): it is more appropriate, they suggest, to think in terms of the explanatory power of qualitative data rather than generalizability. As evidenced by the extracts below, some children's contributions to interviews were remarkable - and while they may not be representative of all ten-year-old children there are, nonetheless, many other children capable of articulating ideas of similar complexity.

Each interview was characterised to a greater or lesser extent by two or three key discussions, occasions when certain images acted as triggers that prompted children to become increasingly involved and to make more reflective responses. In the remainder of this article I presents and interpret a selection of these discussions in order to explore how children reflect upon and articulate their perceptions of beauty. 


\section{Children's perceptions of beauty}

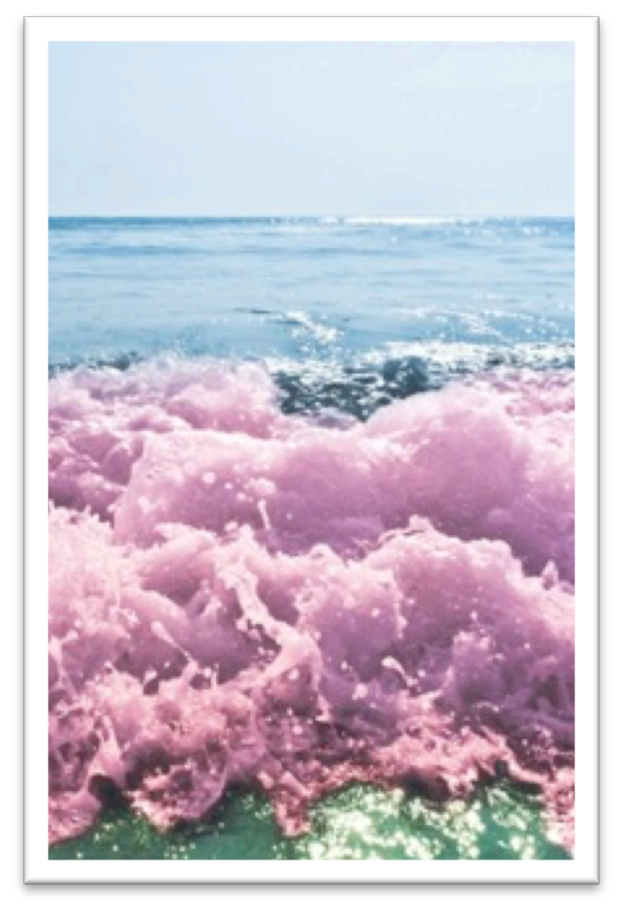

Fig. 3 Ilham's found image: Waves

The range of images children found and photographed suggested they were interested in a range of visual properties and expressive qualities. There were contrasts between the two schools. While children in the urban school tended to find beauty in images that reflected loving relationships, those in the rural school judged the subjective nature of such images to be problematic. These children often photographed landscapes, flowers and animals, suggesting their direct connection with nature influences their perception of it as beautiful. Those in the urban area also found beauty in the natural world but preferred stylised, digitally generated representations of nature designed to appeal to the viewer. A full analysis of the range of content of children's images can be found elsewhere (Watts, Mason and Dura-Vila, forthcoming); this article focuses on evidence of the diversity of children's responses and of their levels of engagement with beauty.

\section{'Glowing as if they were pieces of gold'}

During the interviews some children chose to share images that not only held emotional associations for them but also included visual features they thought others might find beautiful. Ilham shared a photograph of pink waves crashing on a shore (Fig. 3):

I think it's beautiful because of the colours - because there is green and then there's pink and then there's blue. And when I was there it was the first time I ever saw pink waves and I thought it was really beautiful... I went to Egypt and on a beach and when we came there was nobody there and so we took a picture of it and it was really beautiful.

lham's description is intertwined with memories. First she mentions colour, a quality the other children could see and appreciate. But then she explains how the image evokes for her an experience they could not share, in that it represents a particular place and time for her family. When I asked how she felt looking at the photograph she described her sensory associations: 'I feel like the water was just on me... running through my hands'. 'You actually went there?' exclaimed one child, 'I thought you just took it from the computer!' 'The others were from the computer,' said 
Ilham, 'But this is real.' Ilham seemed to want other children to appreciate the visual beauty of the image, yet also to understand that it represented an experience that she could not share with them.

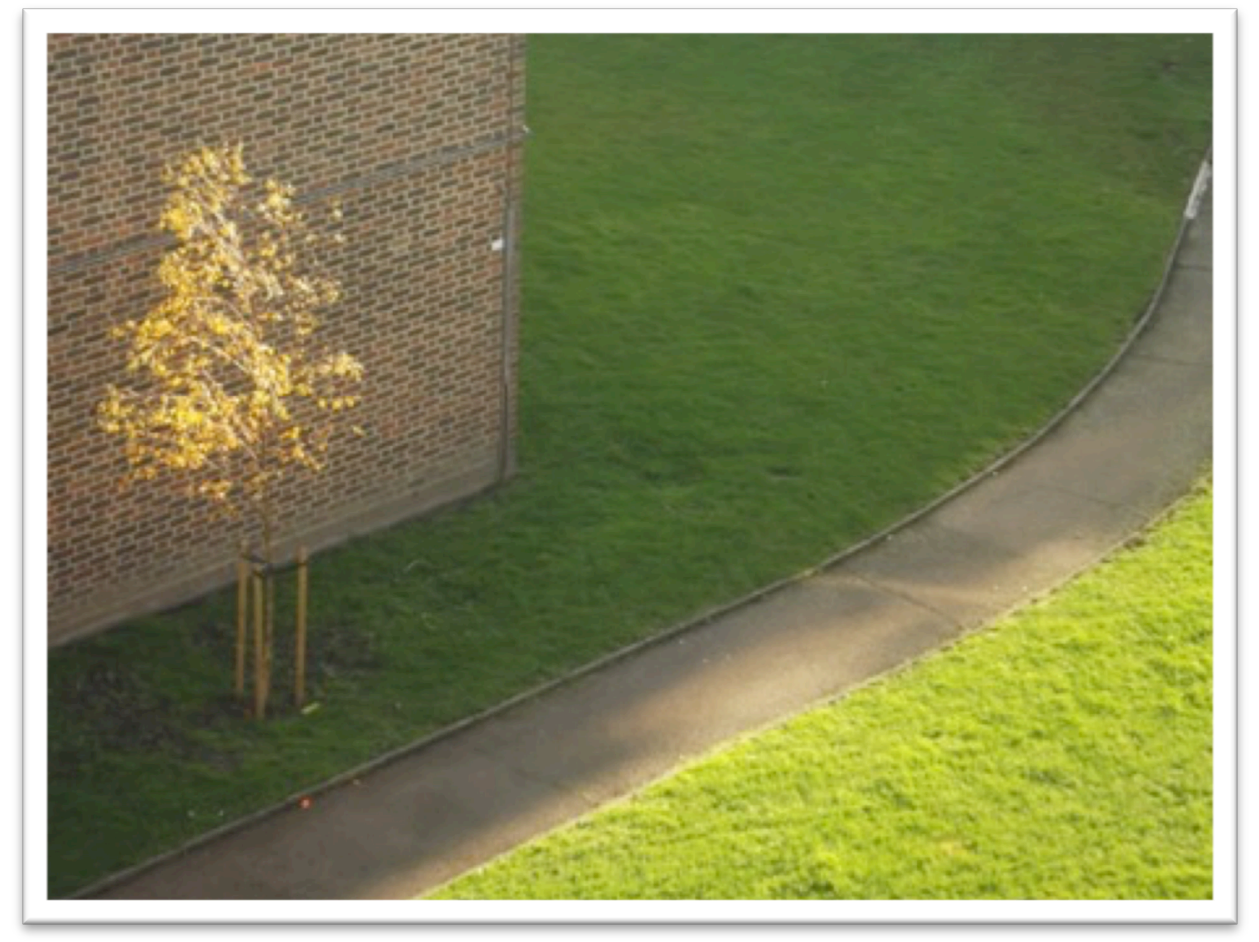

Fig. 4 Kamau's photograph of the view from his balcony

Another discussion at Greystones School revealed some children were aware of how light could momentarily beautify a landscape. Kamaudin shared a photograph taken from his balcony on a housing estate, of a small tree caught in a shaft of sunlight, its yellow leaves illuminated against a brick wall (Fig. 4). A diagonal path bisected two tones of green, the lighter exposed to the sun, the darker immersed in shadow. He explained:

I chose - I chose this because - ummm, I thought it was beautiful. And, like, it was, like that - you know that thingy, walking place - path - I was sitting here. I think it makes it more beautifuller. And the tree as well, that tiny tree. And the colour, I love the colour. It's not just one whole colour, it's like, you know, mixed. Ummm - and, yeah, it's beautiful.

Kamaudin found it difficult to articulate his response to the image and his fractured sentences are a little difficult to decode. Clearly he finds the colours beautiful, he notices the range of tones in the leaves and he seems to understand how the path plays a role in the composition. Others agreed the photograph was beautiful and were surprised when Yonis suddenly disagreed:

I disagree with Billy because - all it is - I could take that every time! I could take that at the middle of the day. It's that walking down to the shopping. What's so beautiful about this? This is green. That's a tree. And a path. Half of it's shaded! ... It's just some greenery and blackery.

In a previous interview Yonis had chosen to share a digital painting of a mysterious, other-worldly landscape he found beautiful, and he seemed offended by the idea that other children could find beauty in something he saw everyday:

Valeriy: I disagree with Yonis because where the sunlight is going it looks like the leaves are glowing as if they were pieces of gold. And the building, it looks like as if [the tree] was being protected. 
RW: $\quad$ Can you explain what you mean by it looks like it was being protected?

Valeriy: Say if someone wanted to - it looks like it's not letting the wind - not letting the wind - it's protecting the tree from the wind... From where he done it he chose a perfect spot to make the picture.

The disagreement proved productive. Yonis's outburst motivated other children to articulate why they thought Kamaudin's photograph was beautiful. Valeriy's description was poetic (the leaves were 'glowing as if they were pieces of gold'), his analysis of the composition was thoughtful ('he chose a perfect spot to make the picture') while his perception of the scene was sensitive ('it looks like as if the tree was being protected').

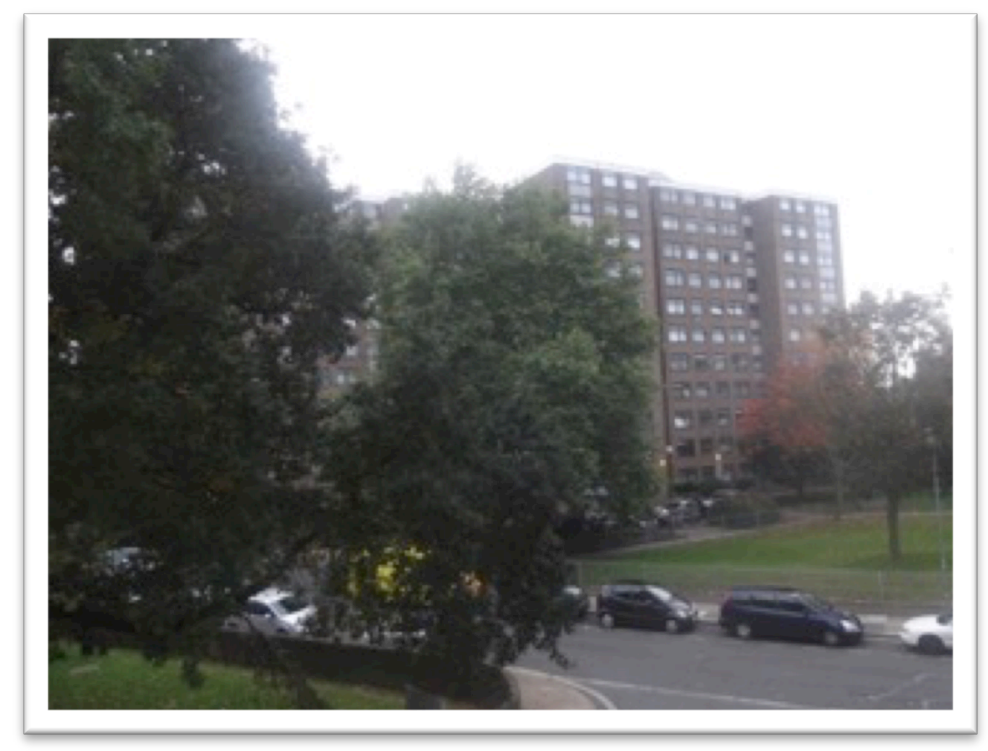

Fig. 5 Enesa's view from her balcony

Similar scenes occurred in other interviews. One group spent 15 minutes discussing Enesa's photograph, taken from her balcony. Some were troubled by the presence of a yellow car in the corner of a photograph, a patch of brightness in an otherwise drab landscape. Though these children had previously agreed that bright colours were beautiful, some argued that this one did not fit the overall colour scheme of the image and thereby detracted from its beauty:

Sherika: The whole picture's nice but the cars are not. When you look at the picture the first thing you recognise is the cars (voices: 'yes') and they don't look nice, especially this yellow one... your eyes are mostly drawn to the yellow one.

Mustafa: Yeah - it's just big and bright and you don't really want to see it.

RW: I thought we liked bright things. You chose something bright.

Mustafa: Yeah, but it's kind of different - because in my picture it's just leaves and grass and stuff like that, but in this one it's, like, a car and you wouldn't want to see a bright yellow car in the middle of your picture.

How might these children have been represented in previous studies of children's aesthetic experience? Parsons (1987) concluded that children of this age were not interested in other people's preferences and that they believed an artwork could only be beautiful if it depicted a beautiful subject. He might have regarded Kamaudin's description of his photograph as further evidence that children simply find beauty in colourful images ('the colour - I love the colour!'). Yet the children I interviewed at Greystones School perceived colour as only one of several visual elements that can make an image beautiful. Ilham loved the pink waves, but her memories of being in the landscape 
shaped her perception of its beauty. The patch of grass Kamaudin passed every day was only 'greenery and blackery' until he photographed its shifting shades. Enesa's friends did not perceive the yellow car in her photograph as a welcome burst of colour in a drab landscape; rather, they saw it as a distraction from the chromatic coherence of the scene. In each case, the context of the group interview enabled children to demonstrate their levels of engagement with their own and others' images.

\section{'Beauty and love and happiness, they're all kind of in a big umbrella-thing.'}

Although I took care to avoid using the word 'art' when I presented the research tasks to children, some children at Old Oak School approached the task almost as if they were artists. While they chose images with visual qualities they thought might appeal to others, the images also helped them to express their broader ideas about the nature of beauty.

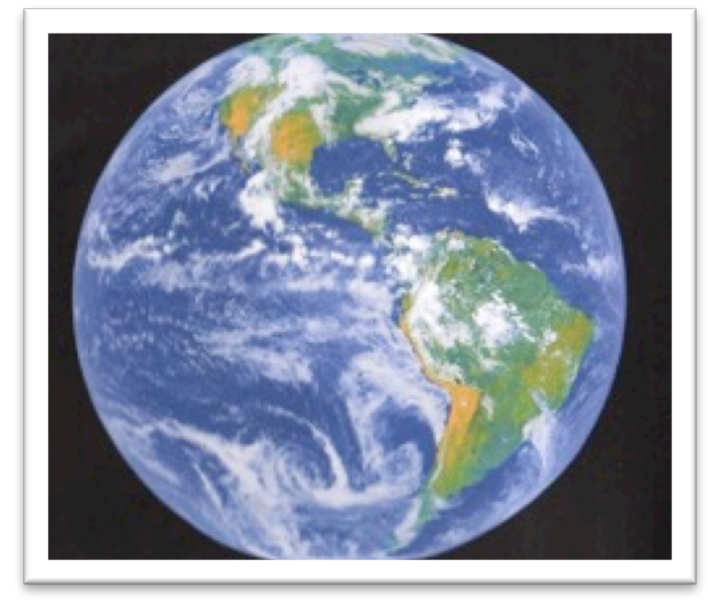

Fig. 6 Jasmine - view of Earth from space

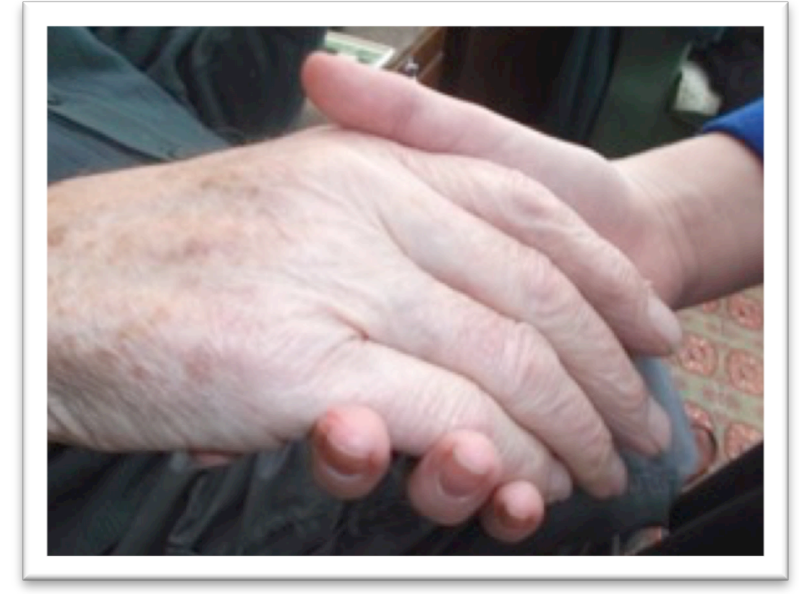

Fig. 7 Jasmine's grandmother and sister

Jasmine approached the task by reflecting on her perceptions of the meanings of beauty. She brought to her first group interview an image of a distant view of the earth (Fig. 6).

Well it's the world - because it's like everyone says the world's a small place but actually it's really big, and everything lives on earth and everything can survive on earth. And it's like the colours blend in and the clouds blend in with the blue ocean and the lands. You can see where you are ... and everything blends in, the ocean, and all of the land, just sort of come together ...

Jasmine explains how she finds the photograph beautiful partly because of its harmonious blend of colours, before alluding to a broader notion of environmental harmony: she finds beauty not only in its visual qualities but also in 'the idea of earth', the 'coming together' of land and sea. Her observation that 'everything lives on earth and everything can survive on earth' suggests a conception of the earth as a shared environment, while her comment that 'you can see where you are' could be interpreted as 'you can see how you fit in as part of a bigger picture'.

During her second interview Jasmine showed she understood how an image could symbolise an idea without explicitly illustrating it. She staged a scene to illustrate her thinking about beauty, photographing two interlinked hands (Fig. 7).

Jasmine: Well, these are members of my family and I think that if members of a family are together ... it just, like, represents love and happiness. And [as] I said before, beauty is not just on the outside, it's also in the inside. 
Bonnie: Yes, because, like Jas said, it's what's on the inside that counts, so it kind of relates to that. And they all link in together because beauty and love and happiness, they're all kind of in a big umbrella-thing because - well, they are all what happens on the inside, not what's on the outside.

Ben: At first I thought - 'cause I didn't really look at the picture properly - I didn't know why Jasmine chose it. I thought 'How could an old wrinkled hand be beautiful?' But when Jasmine made her point about how it's beautiful, it started to change my mind'.

Jasmine intentionally composed her photograph in a way that ensured neither subject was identifiable, thereby de-personalising it and possibly increasing its appeal to others. She may have removed this 'surface layer' of her image in order to make her observation that beauty, love and happiness are all 'what happens on the inside'. As she explained, her concern was to represent the concepts of beauty, love and happiness, rather than to illustrate her personal experience.

Jasmine's images acquire a deeper resonance not only in the context of her explanation but also when viewed alongside each other. In one way, the images could not be more different: one subject is photographed across thousands of miles while the other is within touching distance of the camera. Yet Jasmine's description of their common ground, of how 'everything ... just sort of come[s] together ... everything can survive on earth' evokes a panoramic, holistic, beautiful vision of the earth as an integrated whole. Her image of interlinked hands could be read as a tiny detail of this harmonious vision. The images are also linked by the theme of age and time. The photograph of hands, one old, one young, offers a reminder of how humans change over a lifetime, while the image of earth viewed from space suggests the opposite, that over the course of millions of years the earth looks much the same.

My interpretation of Jasmine's response was that she approached the tasks in much the same way as an artist or designer might, by making purposeful decisions. She made initial decisions about the feelings she intended to express before making further decisions about what she needed to include to communicate the feelings. The longer children talked about the images, the more beautiful they found them. As Ben said: 'At first I thought - 'cause I didn't really look at the picture properly and I didn't know why Jasmine chose it - I thought, how could an old wrinkled hand be beautiful? But when Jasmine made her point about how it's beautiful, it started to change my mind.'

\section{'It's cool because it's in the dirt. That makes it beautiful.'}

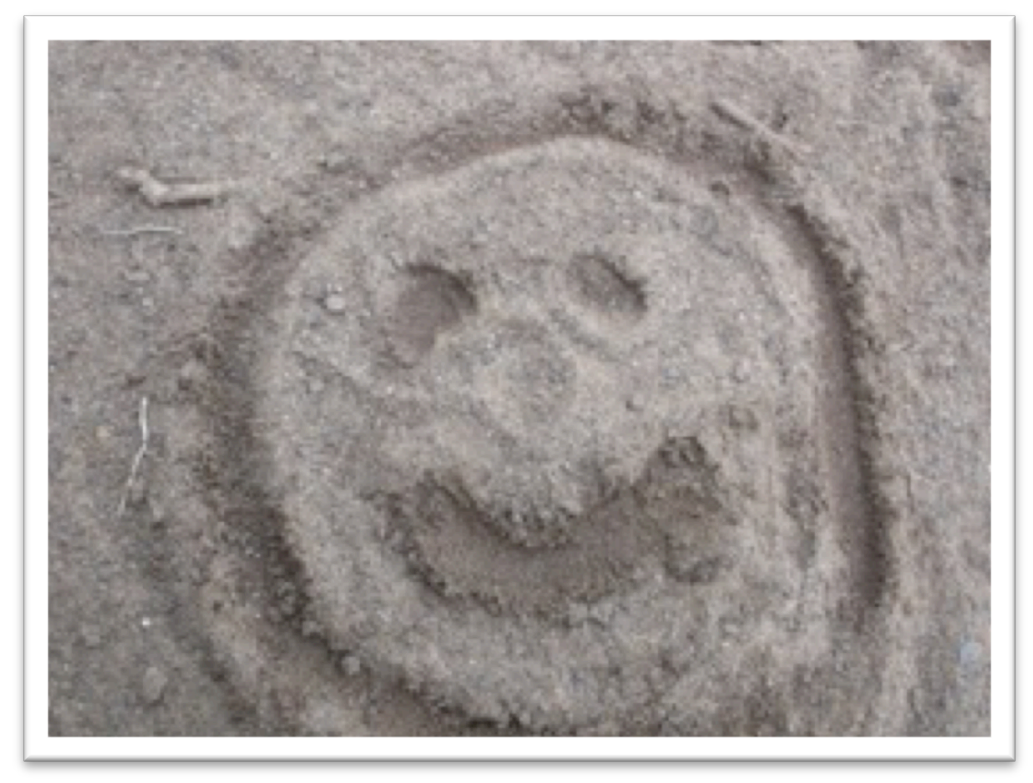

Fig. 8 Spike's smiley face in the sand 
Spike brought drawings to both his interviews. The first was a pencil sketch of a dragon made when he was five years old, and he explained that his memory of making it was central to his perception of it as beautiful: 'I chose it because... I remember when I was doing this and I couldn't draw very well. I put so much effort into it. It made me feel, like, really proud of it which makes me feel it's more than beautiful 'cause I'd put effort in, I'd managed to do that all on my own...' The second was a smiley face drawn in sand and photographed (Fig. 8). Initially I thought Spike had not taken the task seriously. I wondered whether he had intentionally chosen an image made in seconds in order to contrast with the dragon that his five-year-old self had drawn. While the dragon drawing was unique and personal to him, the smiley face was less distinctive, more anonymous. In his previous interview he had proudly described how his drawing of a dragon was 'more than beautiful' because he 'put so much effort into it'. Why would he subsequently share an image made with minimum effort? When I asked Spike why it was beautiful, I was surprised to hear him refer to emotions and memories:

Spike: It reminds me of, like, happy times and things. Things like that, nice memories, smells. And it's cool because it's in the dirt. That makes it beautiful.

RW: Can you explain what you mean? Why does it make it beautiful because it's in the dirt?

Spike: 'Cause - it's ironic. 'Cause dirt's not described as beautiful. Regularly.

RW: What do you mean by ironic?

Spike: Ironic basically meaning opposite. 'Cause if you had dirt you wouldn't think of it as, like, pretty or beautiful, you'd think of it as worthless, something you can just get off the floor. But then like, you can almost use the dirt, in a way, to make things beautiful.

Spike's explanation revealed his intention. The smiley face alone is not beautiful, the dirt is not beautiful - but when combined they become beautiful. The face did more than remind him of the 'happy times' and 'nice memories' he associated with the landscape, it symbolised those experiences. Though it was not clear whether he had planned the photograph to communicate this message, he nonetheless recognized its potential to do so. Like Jasmine, Spike conceptualised the task as an opportunity to create an artwork, as other children recognised:

Gracie: I know you love drawing and doodling - so basically do you mean it's a work of art?

Spike: Yyy.... it's almost like a natural work of art because there's - because art's, like, different, because all art's beautiful in a way, but like, um, but I just think natural, because it's all outside, rather than all cramped up on a piece of paper. When it's outside you can just make it as big as you want, small as you want, detailed as you want. But then as well that just makes it more calm, rather than all busy and things, it makes it like, more beautiful.

Gracie: Yep. That's really good.

Here Spike describes how he finds beauty in the freedom of expression he associates with making art. Though he talks about the way a piece of paper can restrict creativity, it is almost as if he is talking about the confines of art lessons. Given the freedom to express himself, Spike deliberately chose not to showcase his technical ability, and the beauty of the drawing lies in its simplicity.

Spike's reflections on his images contrast with previous accounts of children's perceptions of beauty. Parsons (1987) concluded children of Spike's age admire the technique involved in creating realistic paintings. Furthermore, he argued that children believe paintings can only be beautiful if they represent beautiful subjects. Viewed independently, Spike's image is unremarkable; studied in the context of his commentary on the image, it is a striking representation of his perception of the relationship between emotion, expression and beauty. While Spike's perspective was unusual, is it unique? There are other Spikes in other schools - and when Spike shared his thoughts with his group, other children were not bemused or bewildered; they seemed to understand what he was talking about.

In his assessment of children's aesthetic development, Parsons was, to say the least, cautious about the extent to which children can fully engage with the meanings of art when he said 'There is 
no point in pretending that young children have the abilities of adult artists or critics. It is romanticism to think that their experiences in the arts are equal to those of adults ... Many significant aesthetic qualities are inaccessible to them and their experience of art lacks the richness available to adults' (1987: 27). This may be true of some children, but it risks underestimating the abilities of others. Not only did Jasmine and Spike invest time and thought in selecting their images, they also arrived at their interviews knowing that, in order for others to understand and appreciate their images, they would need to explain why they had chosen them. It is worth noting how quickly and warmly children received their ideas. Though they may not have conceived them themselves, they could nonetheless understand and appreciate them when they heard them expressed. As Gracie said in response to Spike's reflections on his smiley face in the dirt: 'Yep. That's really good.'

\section{Conclusions}

This article reports the findings of a relatively small study. However the findings offer evidence to suggest that beauty has a role to play in art education, as a means of raising children's levels of engagement with the visual world. As the status of art and design in schools remains fragile, there is an increasingly urgent need for art educators to find ways of making the subject meaningful for children. For three decades art educators have proposed that the solution lies in promoting contemporary art practice, that young people will become more engaged with art if they perceive it to be 'relevant' to their lives. My argument is that art educators should explore the depth and diversity of children's existing aesthetic experience, that they should facilitate opportunities for children to reflect upon their experiences of beauty and to recognise the potential of beauty as a means of motivating participation in art.

Children are increasingly swamped by images. Writing recently in Tate Etc. magazine Kevin Jones observed that: 'Images flow at our children like never before. They need to learn to read and interrogate the visual world, to find space to see feelingly and with wonder, to contact and reflect.' (2015: 25) Jones' observation echoes the prescient thoughts of film director Wim Wenders interviewed in 1988: 'Images are escaping our control: they are like a currency of which a whole suitcase is need just to buy one piece of bread' (Malcolm 1988: 1). Since taking part in this research, each child I interviewed has probably used their mobile phone to take hundreds of photographs, and to view thousands more online on tablets and computers. I sometimes imagine images accumulating on cameras like drawings scribbled on millions of pieces of scrap paper, looked at for a few seconds before being discarded. The more children see, the less they notice. The idea of noticing may seem peripheral to the aims of art education, compared with experimenting, creating and risk-taking. However, I would agree with this proposal from Hickman (2010):

I put forward the notion that one of the aims for art education is, or ought to be, concerned with noticing... Visual education must surely concern itself with drawing attention to the subtleties of the visual world, which includes the intriguing, the interesting, the arresting and the beautiful. (Hickman 2010: 149)

The distinction between seeing beauty and noticing beauty is an idea that informed the conception of my own research. Before carrying out the study I was quite sure that children saw beautiful things - but I was unsure whether they recognised them as beautiful.

Art educators have a responsibility to provide opportunities for children to notice - to pause, think, reflect and share their responses to images. Despite the overwhelming number of images children encounter, many of those I interviewed showed how they value images. Some could talk about a single photograph for five, 10 or even 15 minutes, whether it depicted a yellow car parked on a housing estate, a tree illuminated by autumn sunlight or a smiley face drawn in sand. These children demonstrated they are motivated to locate and create images, they are engaged by the beauty of the visual world and inspired to share their experiences. Returning to Steers' (2014) 
vision for art education, this research shows that beauty can be a motivating force for children to achieve the aims of art educators. These children showed they were engaged by images, they were keen to discuss them, they were inspired by beauty and they were able to respond imaginatively when challenged to articulate their ideas about it. Art educators want participation, engagement, inspiration imagination and challenge. Some children might develop these attitudes through contemporary art practice. Others might do so through noticing, appreciating and engaging with beauty. 


\section{References}

Adams, S. (2008) Damien Hirst sale breaks art auction record, raking in $£ 70.5$ million in its first day The Telegraph available at: http://www.telegraph.co.uk/news/2966049/Damien-Hirst-salebreaks-art-auction-record-raking-in-70.5-million-in-its-first-day.html (accessed 6.4.13)

Addison, N. and Burgess, L. (2007) Learning to Teach Art and Design in the Secondary School: A companion to school experience (Second Edition) London: Routledge

Alberge, D. (2012) Tate Brushes aside Old Master Experts The Sunday Times $15^{\text {th }}$ January, p.12

Armstrong, J. (2004) The Secret Power of Beauty London: Penguin

Atkinson, D. \& Dash, P. (Eds.) (2005) Social and Critical Discourses in Art Education Stoke-onTrent: Trentham Books

Bancroft, A. (1995) What Do Dragons Think About in their Dark Lonely Caves? or Critical Studies: The Importance of Knowledge International Journal of Art and Design Education Vol. 14, No. 1 pp. 21-34

Beech, D. (2009) Art and the Politics of Beauty in D. Beech, (Ed.) Beauty London: Whitechapel Gallery

Best, D. (1996) Values in the Arts in J.M. Halstead and M.J. Taylor (Eds.) Values in Education and Education in Values London: Falmer Press

Cannatella, H. (2006) Is Beauty an Archaic Spirit in Education? Journal of Aesthetic Education, Vol. 40, No. 1 pp. 94-103

Danto, A.C. (2003) The Abuse of Beauty: Aesthetics and the Concept of Art Chicago and LaSalle: Open Court

De Botton, A. (2002) On Possessing Beauty in A. De Botton, The Art of Travel London: Hamish Hamilton

Department for Education (DfE) (2013) National Curriculum; Draft document available at: www.education.gov.uk/nationalcurriculum (accessed 28.7.13)

Department for Education (DfE) (2014) National Curriculum; Draft document available at: www.education.gov.uk/nationalcurriculum (accessed 23.6.13)

Eco, U. (2004) On Beauty: A History of a Western Idea (trans. A. McEwen) London: Secker \& Warburg

Eisner, E.W. (1972) Educating Artistic Vision New York: MacMillan

Eisner, E.W. (2002) The Arts and the Creation of Mind New Haven: Yale University Press

Fisher, R. (1998) Teaching Thinking: Philosophical Enquiry in the Classroom London: Cassell

Freeman, N. (1996) Art Learning in Developmental Perspective. International Journal of Art and Design Education Vol. 15, No. 2 pp. 125-132 
Freedman, K. (2003) Teaching Visual Culture: Curriculum, aesthetics, and the social life of art New York: Teachers College Press

Gaut, B. and Gaut, M. (2012) Philosophy for young children: A practical guide Abingdon: Routledge

Gilbert-Rolfe, J. (1999) Beauty and the Contemporary Sublime New York: Allworth Press

Greig, A. Taylor, J. and MacKay, T. (2007) Doing Research with Children (Second Edition) London: Sage

Hickey, D. (1993/2009) Enter the Dragon: On the Vernacular of Beauty, in The Invisible Dragon: Four Essays on Beauty pp. 15-24. Los Angeles: Art Issues Press. Revised and expanded edition (2009) Chicago: University of Chicago Press.

Hickman, R. (2010) Why We Make Art and Why it is Taught (Second Edition) Bristol: Intellect

Housen, A. (1983) The Eye of the Beholder: Measuring Aesthetic Development (Unpublished Doctoral Dissertation Harvard Graduate School of Education)

Hughes, R. (1991) The Shock of the New (Second Edition) London: Thames and Hudson

Jenkins, S. (2009) Beauty is a Dirty Word The Sunday Times (News Review section) $15^{\text {th }}$ March, pp. $1-3$

Jones, K. (2015) Opinion: learning from our children Tate Etc. No. 34 Availbale at: http://www.tate.org.uk/context-comment/articles/opinion-learning-our-children (accessed 27.6.17)

Larsson, S. (2009) A pluralist view of generalization in qualitative research, International Journal of Research \& Method in Education Vol. 32 No.1 pp. 25-38

Lewis, L. (2012) Philosophy for Children Through the Secondary Curriculum London: Continuum Lipman, M. (1982) Philosophy for Children Thinking: the Journal for Philosophy for Children Vol. 3

Machotka, P. (1966) Aesthetic criteria in childhood: Justifications of preference. Child Development, Vol. 37, No. 4 pp. 877-885

Malcolm, D. (1988) Angel Delights: Interview with Wim Wenders The Guardian $23^{\text {rd }}$ June.

Mason, J. (2002) Qualitative Researching London: Sage

Nehamas, A. (2007) Only a Promise of Happiness: The Place of Beauty in a World of Art Woodstock: Princeton University Press

Parsons, M.J. (1987) How We Understand Art New York: Cambridge University Press

Prettejohn, E. (2005) Beauty and Art 1750-2000 Oxford: University Press 
Rautio, P. (2010) Beauty in the Context of Particular Lives Journal of Aesthetic Education Vol. 44, No. 4 pp. $38-59$

Sartwell, C. (2004) Six Names of Beauty London: Routledge

Scarry, E. (2001) On Beauty and Being Just London: Duckworth

Scruton, R. (2009) Beauty Oxford: University Press

Steers, J. (2014) Reforming the School Curriculum and Assessment in England to Match the Best in the World - A Cautionary Tale International Journal of Art and Design Education Vol. 14, No. 2 pp. 6-18

Steiner, W. (2001) Venus in Exile: The Rejection of Beauty in 20th-Century Art New York: The Free Press

Strauss, A.L. and J. Corbin (1990) Basics of Qualitative Research. Thousand Oaks, CA: Sage.

Swift, J. and Steers, J. (1999) A manifesto for art in schools International Journal of Art \& Design Education Vol. 18, No. 1 pp. 7-13

Tate Publications (2001) available at: www.tate.org.uk/about/pressoffice/pressreleases/110501.htm (accessed 13.1.12)

Tate (2012) Press Release: Tate Modern attracts record 5.3 million visitors in 2012 available at: http://www.tate.org.uk/about/press-office/press-releases/tate-modern-attracts-record-53-millionvisitors-2012 (accessed 6.4.13)

Taylor, R. (1989) Critical Studies in Art and Design Education: Passing Fashion or the Missing Element? in Thistlewood, D. (Ed.) (1989). Critical Studies in Art and Design Education. London: Heinemann

Taylor, R. and Andrews, G. (1993). The Arts in the Primary School London: Routledge

Winston, J. (2006) Beauty, goodness and education: the Arts beyond utility Journal of Moral Education Vol. 35 , No. 3 pp. 285-300

Winston, J. (2008) “An Option for Art but Not an Option for Life": Beauty as an Educational Imperative Journal of Aesthetic Education, Vol. 42, No. 3 pp. 71-87

Winston, J. (2010) Beauty and Education London: Routledge

Wolf, N. (1991) The Beauty Myth: How images of beauty are used against women New York: Anchor Books / Doubleday 